\title{
ENHANCING WELLBEING OF EMPLOYEES THROUGH CORPORATE SOCIAL RESPONSIBILITY CONTEXT
}

During last 25 years technological development has accelerated the globalization process which has caused dramatic changes within and across organization. Business performance is varying, complex, global and is changing faster than ever before. Over the time, society expectations have changed, changes have affected customers, partners and employees as well. In order to retain on the global market, organizations integrate corporate social responsibility into their business performance with the objective to reinforce their competitiveness. In the knowledge economy, where knowledge is a significant resource and the demand for more highly skilled workers has increased, employees became the most important and in fact the only remaining realistic challenge of competitive ability. Workplace wellbeing refers to mental, psychological or emotional aspect of employee's life. The awareness of management on the employees' wellbeing which takes into consideration the employees satisfaction, health and professional development is an effective approach in strengthening of an organizational performance. The aim of this paper is to analyze and assess how socially responsible orientation also incorporated in strategic human resource management can contribute to the achievement of wellbeing of employees. Strategic management of human resources includes the necessary coordination between various employees' health and performance aspects. This contributes to the balance between private and working life. Social responsible activities coordinated through strategic human resource management significantly influence the employees' wellbeing as well as competitiveness of the organization.

Key words: corporate social responsibility, strategic human resource management, wellbeing, competitiveness

Karmen Dežmar Krainz, PhD Candidate, Croatian Institute for Health Protection and Safety at Work, Zagreb, Croatia, e- mail: kdezmar-krainz@hzzzsr.hr 


\section{Introduction}

Globalization, technology development, demographic changes and changes in the economic concepts have strongly influenced the changes in human resource management (HRM). The 20 th century is the century of information society while the 21 st century is characterized as the century of knowledge society, where knowledge is significant resource and main competitive part of every organization. ${ }^{1}$ Since last century the awareness of business organizations having some responsibilities to society, beyond that of making profits for the shareholders, is raising. ${ }^{2}$

Laurinavičius and Romeris ${ }^{3}$ claim that corporate social responsibility (CSR) is a commitment of an organization to meet the needs and interests of their stakeholders (shareholders, suppliers, employees, customers, community and others). Employees, being considered as one of the most important internal resource, require special attention because of their key role. In order to achieve competitive advantage, organizations should invest into intellectual human capital, ensuring safe and healthy working conditions for their employees so contributing to their wellbeing. All the aspects of employees' wellbeing make a constituent part of internal dimension of CSR.

\section{The Context of Corporate Social Responsibility}

It is well known around centuries ${ }^{4}$ that business enterprises have some responsibilities to society beyond that of making profits for the shareholders. The concept of CSR significantly varies within specific social context. Some organizations present it as moral obligation towards certain value principles or redistribution of wealth from managers and shareholders to other stakeholders. For other organizations it represents hiding profit maximization or strategy that aims to avoid rigorous legislation in certain business segments, while there

1 Lapina Inga, Maurane Gunta, Starineca Olga (2014): "Human resource management models: aspects of knowledge management and corporate social responsibility", Social and Behavioural Sciences, 110, 577-578

2 Caroll B. Archie, Shabana M. Kareem (2010): “The Business Case for Corporate Social Responsibility: A Review of Concepts, Research and Practise“, International Journal of Management Reviews, 12/ 1, 85

3 Laurinavičius Alfonsas, Romeris Mykolas (2013): „Impact of responsible organisations to ensure socio- economic justice, Industry, Science and Policy Makers for Sustainable Future", Proceedings of the 14th Management International Conference Koper, Slovenia, 21- 23 November 2013., 56, http://www.fm-kp.si/zalozba/ISBN/978-961-266-148-9/papers/ MIC1099.pdf, (08. 04. 2015)

4 Caroll B. Archie, Shabana M. Kareem, 85 
are organizations that using CSR as fashionable rhetoric when communicating with external influential groups. ${ }^{5}$

\subsection{Determination and Definition of Corporate Social Responsibility}

Deliberation of CSR intensively began in the 60's of the last century when public awareness raised together with public expectations that business organizations should invest their financial resources to solve social problems. It is expected from the business organizations to direct their activities on poverty reduction, environmental protection, improvement of public health, better education, etc. ${ }^{6}$ It is simply expected from management not to manage organizations exclusively from proper interest, but to work in synergy with the environment. Some authors distinguish social obligation and social responsibility. According to Bahtijarević - Šiber, et al., social obligation and liability of a company is to satisfy economic and legal duties and responsibilities, while social responsibility is an obligation of the company to follow good long-terms goals for society beyond legal and economical requirements. Thus, social responsibility alongside with the fulfilment of legal and economic obligations imposes ethical obligation for management to act in the society interest. ${ }^{8}$ In the past 50 a large number of different definitions of CSR have appeared which are complete opposite to the initial Friedman's definition" "the social responsibility of business is to increase its profits." Carroll's definition of social responsibility has been successfully used for research purposes for many years. He differs four different categories of social responsibility involving the fulfilment of economic, legal, ethical and discretionary/philanthropic responsibilities. ${ }^{10}$ According to Carroll ${ }^{11}$ "the social responsibility of business encompasses the economic, legal, ethical and discriminatory [later referred to as philanthropic] expectations that society

5 Omazić A. Mislav (2007): „Društvena odgovornost i strategije hrvatskih poduzeća“, $\mathrm{PhD}$ Thesis, University of Zagreb, Faculty of Economic and Business, 40

6 Bahtijarević- Šiber Fikreta, Sikavica Pere, Pološki Vokić Nina (2008): „Suvremeni menadžment - vještine, sustavi i izazovi“, Školska knjiga, Zagreb, 561

Ibid, 562

Ibid.

Friedman Milthon (1970): „The social responsibility of business is to increase its profits”, The New York Times Magazine, September 13, 122, http:/query.nytimes.com/mem/ archivefree/pdf?res=9E05E0DA153CE531A15750C1A96F9C946190D6CF, (07 04 2015)

10 Caroll B. Archie, Shabana M. Kareem, 89

11 Carroll, A.B.(1979): "A three-dimensional conceptual model of corporate social performance", Academy of management Review, 4, 497- 505 (1991): “The pyramid of corporate social responsibility: towards the moral management of organizational stakeholders", Business Horizons, July - August, 39- 48, referenced by Carroll, A. B., Shabama, K.M., (2010): “The Businesss Case for Corporate Social Responsibility: A Review of Concepts, Research and Practise", International Journal of Management Reviews, 12/1, 89 
has of organizations at a given point in time". This definition made a distinction between traditional and new approach to the CSR, which it includes, ethical and discretionary/philanthropic responsibilities reflecting comprehensive social link between business and society, apart from traditionally considered economic and legal responsibilities. It is also well known in the literature the Carroll's Pyramid of CSR which illustrates his definition. Carroll's CSR pyra$\mathrm{mid}^{12}$ represents four levels indicating relative importance of economic, legal, ethical and philanthropic responsibility. His fourth - part, conceptualisation has been the most cited one. The model incorporates and gives priority to the economic dimension which is an aspect of CSR.

Figure 1: The Pyramid of Corporate Social Responsibility

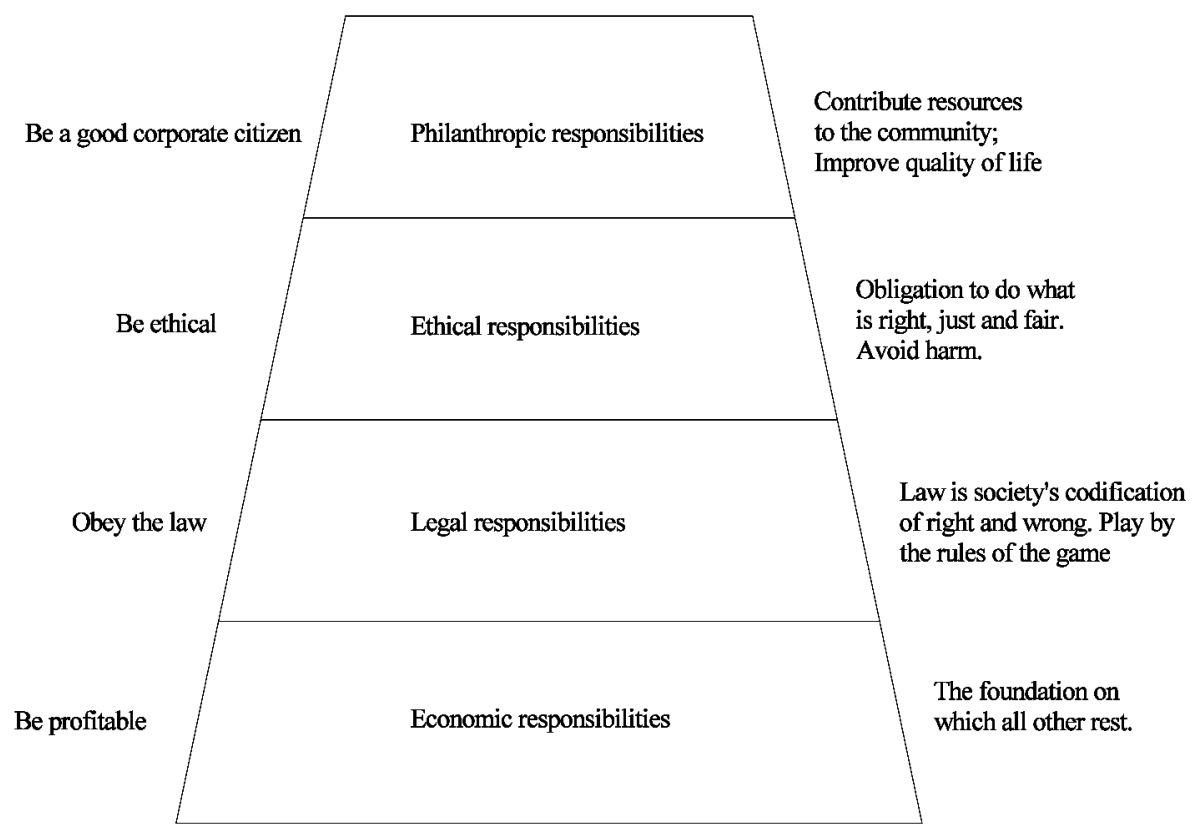

Source: Wayne (2007): Revisiting Carroll's CSR Pyramid: An African Perspective, In A. Crane \& D. Matten (eds.), Corporate Social Responsibility: Three Volume Set, London: Sage, 34, http://www.waynevisser.com/wpcontent/uploads/2012/04/chapter_wvisser_ africa_csr_pyramid.

12 Wisser Wayne (2007): “Revisiting Carroll's CSR Pyramid: An African Perspective”, In A. Crane \& D. Matten (eds.), Corporate Social Responsibility: Three Volume Set, London: Sage, 33, http://www.waynevisser.com/wpcontent/uploads/2012/04/chapter_wvisser_africa_ csr_pyramid.pdf, (29 03 2015) 
Basically, Kotler and Lee ${ }^{13}$ defines CSR in the similar way, as "a commitment to improve community's well - being through discretionary business practices and contributions of corporate resources."

European Union's Green Paper entitled ${ }^{14}$ "Promoting a European Framework for CSR" differ two dimensions of CSR internal and external dimension. Internal dimension encompasses HRM, health and safety at work, adoption of changes in management of environmental impacts and natural resources. It represents issues related to internal stakeholders of an organization such as investing in human capital, health and safety, managing changes and all employees' welfare, training, education, participation etc. with the aim to enhance their wellbeing. ${ }^{15}$ External dimension comprehends local communities, business partners, suppliers and consumers. The external dimension represents external organization stakeholders like customers and consumers, local communities, business partners and suppliers and its impact to public life in sense of human rights, and global environmental concerns, etc. Furthermore, the question is what motivates business organizations to incorporate CSR and what are the tangible benefits from involving CSR activities, practice, strategies and policies into their business. The business case for CSR relates to the specific economic and financial benefits, incorporating socially responsible activities and practise. The rationale of the business case for CSR may be categorized under four arguments: ${ }^{16}(1)$ reducing cost and risk; (2) strengthening legitimacy and reputation; (3) building competitive advantage; and (4) creating win - win situations through synergistic value creation. In the $21^{\text {st }}$ century being socially responsible means to go beyond legal requirements and invest "more" in human capital, environmental issues and relations with

13 Kotler Philip, Lee Nancy (2009): „Društveno odgovorno poslovanje“, M.E.P. Counsult d.o.o., Zagreb, 14

14 European Commission (2001): Green Paper: "Promoting a European Framework for Corporate Social Responsibility", http://www.google.hr/url?sa=t\&rct=j\&q=\&esrc=s\&sou rce=web\&cd=1\&ved=0CCUQFjAA\&url=http\%3A\%2F\%2Feuropa.eu\%2Frapid\%2Fpressrelease_DO9_en.pdf\&ei=FnotVZiGNov XavOGgfgO\&usg=AFQjCNF-ef7j_hp0XUAG_ mtQ16dSt6dpOQ\&bvm=bv.90790515,d.d2s,(07 04 2015)

15 Polášek David (2010): "Corporate Social Responsibility in Small and Medium Sized Companies in the Czech Republic", PhD Thesis, Czech management Institute Praha, Faculty of Management, Escuela Superior de Marketing y Administración Barcelona, 56, www.csr-online.cz/wp-content/uploads/2012/.../DP_David_Polasek.doc (31 03 2015)

16 Kurucz, E., Colbert, B. and Wheeler, D., (2008): “The business case for corporate social responsibility". In Crane, A., Mc Williams, A., Matten, D., Moon, J. and Siegel, D. (eds), The Oxford Handbook of Corporate Social Responsibility, Oxford; Oxford University Press, 83 -112, referenced by Carroll, A. B., Shabama, K.M., (2010): "The Businesss Case for Corporate Social Responsibility: A Review of Concepts, Research and Practise”, International Journal of Management Reviews, 12/1, 101 
stakeholders. Nowadays CSR is based on social, environmental and economic responsibility. ${ }^{17}$

\section{Strategic Human Resource Management}

Today, one of the major challenges for an organization is to attract and retain skilled and highly motivated workers.$^{18}$ The concept of HRM has been permanently developed since the 80 's of the last century. Nowadays practice of HRM treats people as the most important organization capital, developing resource as well as source of strategic competitive advantage. Investing in people is considered to be the most profitable investment in business performance. ${ }^{19}$ Employees are the most important assets of an organization that is very strategic instrument for company market competition. ${ }^{20}$ One of the most important tendencies in the HRM development is emphasizing its strategic role and importance as well as exceptional development strategies of HRM. Strategic human resources management (SHRM) becomes significant and dominant new phase in development of HRM and its synonym. In fact it can be said that the concept of SHRM replaces the usual conception of HRM since everything what is done in HRM has a strategic importance and consequences. Its growing importance it is considered as the follow up of the constant HRM evolution. It connects and merges HRM with strategic management of the organization. SHRM enables that business objectives and organization strategy are aligned with the goals and strategies of human resource (HR) and acquires sustainable competitive advantage through people. In other words it defines the intensions of organizations how to achieve their business goals by people. ${ }^{21}$ In order to meet competitive changes HRM must go beyond functional level and should be strategic partner in the organization. ${ }^{22}$ Dave Urlich ${ }^{23}$ was the first who put together the term "HR as a

\footnotetext{
17 Lapina Inga, Maurane Gunta, Starineca Olga, 579

18 Polášek David, 56

19 Bahtijarević- Šiber Fikreta (2014): Strateški menadžment ljudskih potencijala, suvremeni trendovi i izazovi, Školska knjiga, Zagreb, 12

20 Oraman Yasemin, Unakitan Gökhan, Selen Ufuk (2011): "Measuring Employee Expectations in a Strategic Human Resource Management Research: Job Satisfaction", Social and Behavioural Sciences, 24, 413

21 Bahtijarević- Šiber Fikreta, 41-58

22 Bas Abdurrahman, (2012): "Strategic HR Management: Strategy Facilitation Process by HR", Procedia-Social and Behavioural Sciences, 58, 313

23 Urlich Dave (1996): „Human Resource Champions“, Harvard Business Press, Boston, referenced by Bas Abdurrahman, A. (2012): "Strategic HR Management: Strategy Facilitation Process by HR, Procedia-Social and Behavioural Sciences, 58, 313
} 
strategic partner" in organizations. According to Urlich ${ }^{24}$ four distinct roles of HR professionals are: administrative expert, employee champion, change agent and strategic partner. HR professionals must operate coordinated in all four areas in order to contribute the traditional functional HR orientation to a more strategic orientation. Strategic partnership is the prominent task of the HRM today and it relates to sharing the responsibility of the strategic initiatives and alignment of HR activities with the business strategy. ${ }^{25}$ Bas argues $^{26}$ that HR can be only a real strategic partner if it (1) understands the business and takes its part in the strategy formulation process, (2) spreads the strategic word thought the organization, (3) takes an active role in the implementation of it and (4) generates the necessary competencies for the accomplishment of the strategy. Oraman, et al., ${ }^{27}$ introduce "human advantage" as being competitive strategy and system- based view of the value of HR which makes towards adding value to customers, towards managing cost, through accelerating operational and management processes, and in challenging the status quo through innovation and change. "Human advantage" tell us that in information time, human capital is the key resource to reach the competitiveness rather than physical assess or financial resources. In recent years, more and more emphasizes the value of human capital or intellectual capital which represents the intangible assets such as knowledge, ideas, creativity, competence etc. ${ }^{28}$ According to Bahtijarević- Šber ${ }^{29}$ the main characteristics of the human capital concept are: focus on value creation, HR as a key asset of the organization, the role of $\mathrm{HR}$ and HRM in creating value; measuring their contribution to value and organizational success and highlighting systematic reviews and decision making based on the analysis and objective data. Some authors argue that is necessary to establish a strategic link between the internal resources of the organization and their environment, while the success of an organization is not based only on its internal strengths. ${ }^{30}$ SHRM achieves the synergy between organizational

\footnotetext{
$24 \quad$ Ibid.

25 Ibid, 314

26 Ibid.

27 Oraman Yasemin, Unakitan Gökhan, Selen Ufuk (2011): "Measuring Employee Expectations in a Strategic Human Resource management Research: Job Satisfaction", Social and Behavioral Sciences, 24, 414

28 Bahtijarević- Šiber Fikreta, 25

29 Ibid.

30 Barrena- Martines Jesus, López- Fernández Macarena, Romero- Fernández, M. Pedro (2011): "Research proposal on the relationship between corporate social responsibility and strategic human resource management", International Journal of Management and Enterprise Development, 10/ 2-3, 174
} 
strategies and HR polices practices and activities and can prevent the positional threats and lead to competitive advantages in the organization. ${ }^{31}$

\section{The Concept of Employees' Wellbeing}

The research of wellbeing at the workplace is becoming a growing topic. In the past this topic referred to the absence of disease and was bounded to physical health, while nowadays it has a broader connotation, involving physical, emotional, mental and social aspects. Individual experiences at work can physically, emotionally, mentally and socially influence an employee, hence they spend at least one third of a working day. Working time and free time of an individual are not separated entities because very often workers do not necessarily leave their job behind when they leave the workplace. Those two entities very often overlap, which opens the space for extensive research in this area. ${ }^{32}$ The basic study of wellbeing comes from motivation theories which attempt to explain the reason why people behave the way they do and what causes of their behavior. Organization should consider employee's needs, investigate what makes them feel good and motivate them to work better. ${ }^{33}$ Health and wellbeing in the workplace has become a common topic in organization research due to their mutual influence, and it is very difficult to analyze them separately. Figure 2 presents an organizational framework pointing out the factors which create wellbeing in the workplaces.

The third factor is occupational stress which also has direct impact on health and wellbeing. Occupational stress arises as a consequence of lack of harmony between individual needs and demands and those of the environment. In other words, occupational stress occurs when demands at work are above employee's capacity to deal with them. Cooper and Marshal ${ }^{34}$ conceptualized six potential sources of occupational stress as follows: (1) factors intrinsic to the job (i.e. work overload, shift work, long hours, travel, risk and danger, new

31 Gilani, H.N. Mahnaz, Zadeh, S. Mohamed, Sanderi, R. Hamid (2012): “The Role of Strategic Human Resource Management in Creation of Competitive Advantages (Case Study: A Commercial Organization in Malaysia"), International Journal of Business and Social Science, 3/16, 237, http://ijbssnet.com/journals/Vol_3_No_16_Special_Issue_ August_2012/24.pdf, (19 03 2015)

32 Danna Karen, Griffin W. Ricky(1999): "Health and Well- Being in the Workplace: A Review and Synthesis of the Literature", Journal of Management, 25/3, 358

33 De Simone Stefania (2014): “Conceptualizing Wellbeing in the Workplace”, International Journal of Business and Social Science, 5/12, 118, http://ijbssnet.com/journals/vol_5_ no_12_november_2014/14.pdf, (07 04 2015)

34 Cooper, C. L., \& Marshall, J. (1978): “Understanding executive stress”, London: Macmillan, referenced by Danna Karen, Griffin W. Ricky (1999): "Health and Well- Being in the Workplace: A Review and Synthesis of the Literature”, Journal of Management, 25/3, 371 
technology and the quality of the physical working environment), (2) role in the organization (i.e. role ambiguity, role conflict as well as the degree of responsibility for others), (3) relationship at work (i.e. with superiors, colleagues and subordinates), (4) career development together with job insecurity, (5) organizational structure and climate (i.e. lack of participation and effective consultation, poor communication, politics and the consequences of downsizing), (6) home/work interface (balance between private and working life).

Figure 2: A Framework for Organizing and Directing Future Theory, Research, and Practice Regarding Health and Wellbeing in the Workplace

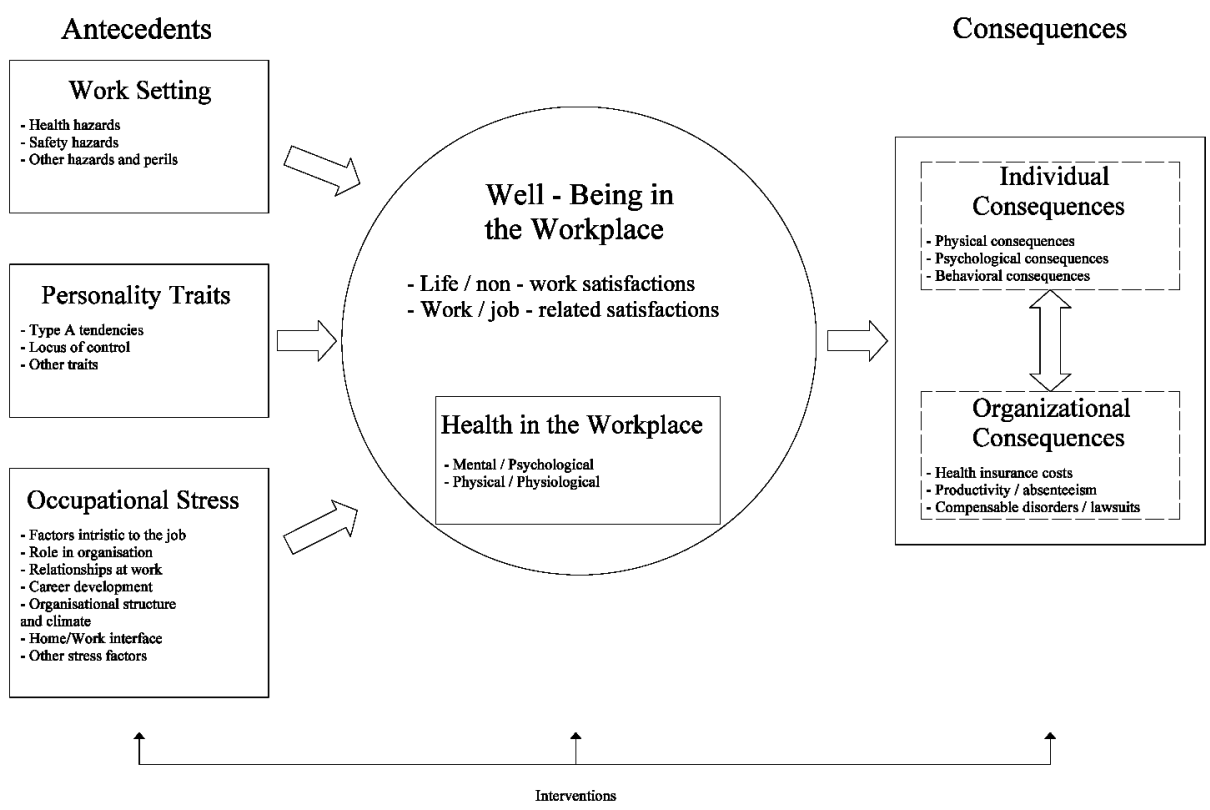

Source: Danna Karen, Griffin W. Ricky (1999): "Health and Well- Being in the Workplace: A Review and Synthesis of the Literature", Journal of Management, 25/3, 360

New technologies, the move from manufacturing to service - based economics as well as globalization have caused all sorts of extensive changes and rapid lifestyle which has imposed the new and intensified the existing psychosocial risks such as the aging workforce and population, increase in the number of women in the workforce, and the transformation of work patterns. The above mentioned circumstances have inevitably required a new concept of keeping employees healthier, which in turn can increase the length of time spent 
in the workforce. ${ }^{35}$ According to European Agency for Safety and Healthy at Work (EU OSHA) ${ }^{36}$, psychosocial risk arise from work design, organization and management, as well as a poor social context of work, and they may result in negative psychological, physical and social outcomes such as occupational stress, burnout or depression. Recent defining of occupational stress differs from the concept mentioned by Danna and Griffin ${ }^{37}$, as the concept comprehension has been developed. Psychosocial risks ${ }^{38}$ have been defined as those aspects of the design and management of work, and its social and organizational context, that have the potential for causing psychological or physical harm. Danna and Griffin framework ${ }^{39}$ also identifies two levels of consequences related to the wellbeing in the workplace. The first level reflects the consequences for an individual including physical, psychological and behavioral consequence. The second level has implications to organizations and includes health insurance costs, productivity and absenteeism as well as compensable disorders/ lawsuits. These two levels are interfering with each other.

\subsection{The Role of Occupational Health and Safety in Maintaining Employees' Wellbeing}

Occupational Health and Safety (OSH) is one of the key activities of HRM. It is defined as ${ }^{40}$ "a set of technical, medical, legal, social and other measures and activities aiming to prevent and eliminate the hazards and harmful effects that could threaten the lives and health of people at work". The role of OSH is to create a safe working environment and to protect employees from potential accidents, occupational diseases as well as work related diseases. According to EU OSHA Report ${ }^{41}$ in 2002 the European Commission calculated the cost of

35 EU OSHA (2013): Report- Well- being at work: creating a positive work environment, literature review, 1, https://osha.europa.eu/en/publications/literature_reviews/well-beingat-work-creating-a-positive-work-environment, (07. 04. 2015)

36 EU OSHA (2014b): Report- Psychosocial risk in Europe prevalence and strategies from prevention, 10, https://osha.europa.eu/en/publications/reports/psychosocial-risks-euprevalence-strategies-prevention, (07. 04. 2015)

37 Danna Karen, Griffin W. Ricky, 370

38 Cox, T., Griffiths (2005): „The Nature and Measurement of Work- Related Stress“, in J. Wilson and N. Corlett (eds.), Evaluation of Human Work: A Practical Ergonomics Methodology, 3rd edition (CRC press, Boca Raton, FL), 553- 573, refrenced by Jain Aditya, Leka Stavroula, Zwetsloot Gerard, (2011): "Corporate Social Responsibility and Psychosocial Risk Management in Europe”, Journal of Business Ethics, 101, 622

39 Danna Karen, Griffin W. Ricky, 359

40 Ivandić Vidović Darija, Karlović Lidija, Ostojić Alen, (2011): Korporativna sigurnost, Udruga hrvatskih menadžera sigurnosti- UHMS, Zagreb, 2011, 257

${ }^{41}$ EU OSHA (2014a): Report-Calculating the cost of work-related stress and psychosocial risks, 4-7, https:/osha.europa.eu/en/publications/literature_reviews/calculating-the-cost- 
work related stress in the EU - 15 at $€ 20$ billion per year. Among the employees suffering work - related health problems, stress, depression or anxiety was reported as the most serious health problem by $14 \%$. In 2010 the European Survey of Enterprises on the New and Emerging Risks (ESENER) showed that managers are also aware of this issue, with finding that $79 \%$ of European managers are concerned about stress in their workplaces.

Furthermore, less than $30 \%$ of organizations in Europe have procedures for dealing with occupational stress, harassment and third - party violence. ESENER has shown that more than $40 \%$ of European managers consider that psychosocial risk is more difficult to manage than traditional OSH risk. In 2013 the cost to Europe of work related depression was estimated to

$€ 617$ billion annually. The total was made up of costs to employers resulting from absenteeism and presentism ( $€ 272$ billion), loss of productivity (€242 billion), health care cost (€63 billion) and social welfare costs in the form of disability benefit payments ( $€ 39$ billion).The above mentioned figures show that the problem with the psychosocial risks and their consequences is quiet huge in financial, medical and social terms and only coordinated OSH activities can mitigate their negative effects.

\section{The Influence of Corporate Social Responsibility to Wellbeing}

The raising awareness of CSR activities induces the questions on how socially responsible organizations influence the employee's wellbeing. It is big challenges for SHRM how to recruit, retain and motivate employees applying socially responsible principles. Nowadays employees are more and more aware of the responsibility of organizations towards society.

The essential approach to CSR has its roots in the stakeholder theory and says that long term value of organization rests primarily on the knowledge, abilities and commitment of its employees and its relationship with investors, customers and other stakeholders. ${ }^{42}$ The role of managers is to satisfy different stakeholders which can influence their organization. According to stakeholders' view it is useful for an organization to engage CSR activities that stakeholders find important in order to get their support for organization. ${ }^{43}$

of-work-related-stress-and-psychosocial-risks (07. 04. 2015)

42 Wheeler, D., Sillanpää, M (1997): „The stakeholder corporation“, London: Pitman, referenced by Tamm Katrin, Eamets Raul, Motsmees Pille (2010): “Relationship Between Corporate Social Responsibility and Job Satisfaction: The case of Baltic Countries”, 9, http://www.mtk.ut.ee/sites/default/files/mtk/RePEc/mtk/febpdf/febawb76.pdf, ( 0804 2015)

43 Tamm Katrin, Eamets Raul, Motsmees Pille (2010): "Relationship Between Corporate Social Responsibility and Job Satisfaction: The case of Baltic Countries", 9, http://www.mtk. ut.ee/sites/default/files/mtk/RePEc/mtk/febpdf/febawb76.pdf ( 0804 2015)

Vol. 12, No 2, 2015: 137-154 
The following figure developed by Tamm, et al. ${ }^{44}$ shows the input - output analysis framework which shows the relations between employee's wellbeing and CSR.

Figure 3: CSR in the input - output framework

\section{INPUT}

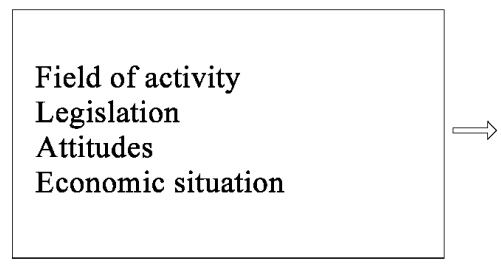

\begin{tabular}{|c|c|c|c|}
\hline \multirow{2}{*}{$\begin{array}{l}\text { CSR } \\
\text { activities }\end{array}$} & Internal & $\Longrightarrow$ & $\begin{array}{l}\text { EMPLOYEES } \\
\text { Well - being }\end{array}$ \\
\hline & External & $\Longrightarrow$ & $\begin{array}{l}\text { OTHER } \\
\text { STAKEHOLDERS }\end{array}$ \\
\hline
\end{tabular}

Source: Tamm Katrin, Eamets Raul, Motsmees Pille (2010): Relationship Between Corporate Social Responsibility and Job Satisfaction: The Case of Baltic Countries, 10, http:// www.mtk.ut.ee/sites/default/files/mtk/RePEc/mtk/febpdf/febawb76.pdf

The framework has tree elements: input, output and CSR activities in the middle. Input to CSR activities represents activities inside the organization which are determined by the general background in economy such as economic situation, legislation, attitudes and the field of activity. Output of CSR activities is related to employees' and other stakeholder's wellbeing. This model tries to connect internal and external social responsibilities. Internal CSR is directly linked to employees' wellbeing and can be measured through job satisfaction indicators which answer what employees expect from the organization. The literature suggests that employees expect that organization demonstrates its social responsibility towards them by guaranteeing considerable rewards and recognition, offering personal development opportunities and work - life balance, ensuring $\mathrm{OSH}$, involvement and empowerment as well as good retirement benefits. ${ }^{45}$ The empirical evidence shows that organizations undertaking CSR actions can face more efficiently the pressures and social demands from the environment and their stakeholders. ${ }^{46}$ If an organization is viewed as socially

Ibid.

45 Maiganan, I., Ferrell, O. C., Ferrell, L. (2005): "A stakeholder model for implementing social responsibility in marketing", European journal of marketing 39 (9/10), 956- 977, referenced by Tamm Katrin, Eamets Raul, Motsmees Pille (2010): "Relationship Between Corporate Social Responsibility and Job Satisfaction: The case of Baltic Countries", 12, http://www.mtk. ut.ee/sites/default/files/mtk/RePEc/mtk/febpdf/febawb76.pdf (08. 04. 2015)

46 Bhattacharya, C., Korschun, D. and Sen, S. (2008): "Strengthening stakeholder- company relationships through mutually beneficial corporate social responsibility initiatives", Journal 
responsible in favour of the community and is fulfilling its social obligations, employees also tend to assess it responsible towards them. ${ }^{47}$ The empirical research based on the survey of 3637 employees in Estonia, Latvia and Lithuania conducted by Tamm, et al. ${ }^{48}$ has confirmed positive link between CSR and wellbeing of employees. Employees feel more satisfied in the organizations committing themselves more socially responsible. This indicates that developing socially responsible practices can be seen as a means to enhance job satisfaction among the employees. Employees play an important role in implementation of organizational strategies, especially CSR strategies. Referring to Sharma et $\mathrm{al}^{49}$ a strong organizational culture reinforced by responsible HR management practice can ensure high level of success in the market by improvement of employee's satisfaction, their productivity, customer loyalty, legal compliance and the approval of society. SHRM concept mentioned by Martin- Alcazar et al. ${ }^{50}$ represents an evolution of the traditional HR concept towards a new integrative perspective which includes: a vertical link with the strategic management process, a horizontal link with the HR practices and an external link with other organizational and environmental factors. Implementing CSR activities through SHRM helps to retain and motivate employees, and increases their wellbeing and reinforces organizational performance and sustainability.

of Business Ethics, 85/2, 257- 272, referenced by Barrena- Martines Jesus, López- Fernández Macarena, Romero- Fernández, M. Pedro (2011): "Research proposal on the relationship between corporate social responsibility and strategic human resource management", International Journal of Management and Enterprise Development, 10/ 2-3, 174

47 Tamm Katrin, Eamets Raul, Motsmees Pille, 13

48 Ibid., 15

49 Sharma, S., Sharma J. and Devi, A. (2009): "Corporate social responsibility: the key role of human resource management”, Business Intelligence Journal, 2, 205- 213, referenced by Barrena- Martines Jesus, López- Fernández Macarena, Romero- Fernández, M. Pedro (2011): "Research proposal on the relationship between corporate social responsibility and strategic human resource management", International Journal of Management and Enterprise Development, 10/ 2-3, 177

50 Martin- Alcazar, F., Romero- Fernández, P., Sanchez- Gardey, G. (2005): "Strategic human resource management: integrating the universalistic, contigent, configurational and contextual perspectives", Int. J. Human Resource Management, 16/5, 633- 659 \& Martin- Alcazar, F., Romero- Fernández, P. , Sanchez- Gardey, G. (2008): "Human resource management as a field of research", British Journal of Management, 19/2, 103- 119, referenced by Barrena- Martines Jesus, López- Fernández Macarena, RomeroFernández, M. Pedro (2011): "Research proposal on the relationship between corporate social responsibility and strategic human resource management", International Journal of Management and Enterprise Development, 10/ 2-3, 177 


\section{Conclusion}

Today organizations play a vital role in the development of society and their duties go beyond their economic functions and legal requirements. In order to satisfy stakeholders' expectations they incorporate social, ethical and environmental commitments to their business performance. CSR as a comprehensive concept incorporated into organization strategy increases their competitiveness. In the new global economy, employees have become a central point for organizations as one of the factors to gain competitive advantage. ${ }^{51}$ In the past the employee was simply an executor of the given task, but today human capital is in the center of an organization and can significantly contribute to the achievement of organization goals. The development of technology is significant which opens a wide space for competitiveness improvement through investment in human capital. Organizations committed to implement CSR activities into their business performance significantly influence the employee's wellbeing. Wellbeing at work as a comprehensive concept, including well balanced physical, psychical, emotional and social issues inside and outside of a workplace, contributes to the total personal benefit of each employee, as well as to the organization long- term effectiveness and competiveness.

\section{Literature}

- Barrena - Martines Jesus, López - Fernández Macarena, Romero - Fernández, M. Pedro (2011): "Research proposal on the relationship between corporate social responsibility and strategic human resource management", International Journal of Management and Enterprise Development, 10/(2-3), 173- 187

- Bas Abdurrahman (2012): "Strategic HR Management: Strategy Facilitation Process by HR”, Procedia- Social and Behavioural Sciences, 58, 313- 321

- Caroll B. Archie, Shabana M. Kareem (2010): “The Business Case for Corporate Social Responsibility: A Review of Concepts, Research and Practise", International Journal of Management Reviews, 12/1, 85-105

- Bahtijarević- Šiber Fikreta (2014): Strateški menadžment ljudskih potencijala, suvremeni trendovi i izazovi, Školska knjiga, Zagreb

- Bahtijarević Šiber Fikreta, Sikavica Pere, Pološki Vokić Nina, (2008): Suvremeni menadžment- vještine, sustavi i izazovi, Školska knjiga, Zagreb

- Danna Karen, Griffin W. Ricky (1999): "Health and Well- Being in the Workplace: A Review and Synthesis of the Literature", Journal of Management, 25/3, 357- 384

51 Zakaria Maziana, Kamaruzaman A. Nik, Ali, Norli, (2014): “The role of wellbeing on performance in service sector”, Social and Behavioural Science, 164, 359 
- De Simone Stefania (2014): "Conceptualizing Wellbeing in the Workplace", International Journal of Business and Social Science, 5/12, 118- 122, http:// ijbssnet.com/journals/vol_5_no_12_november_2014/14.pdf., (07 04 2015)

- European Commission (2001): Green Paper: Promoting a European framework for Corporate Social Responsibility, http://www.google.hr/url?sa= $\mathrm{t} \& \mathrm{rct}=\mathrm{j} \& \mathrm{q}=\& \mathrm{esrc}=\mathrm{s} \&$ source=web \&cd=1\&ved=0CCUQFjAA\&url=http\%3A\%2F\%2Feu ropa.eu\%2Frapid\%2Fpress-release_DO9_en.pdf\&ei=FnotVZiGNov XavOGgfgO\&usg =AFQjCNF-ef7j_hp0XUAG_mtQ16dSt6dpOQ\&bvm=bv.90790515,d.d2s (07. 04. 2015)

- EU OSHA (2014a): Report- Calculating the cost of work- related stress and psychosocial risks, https://osha.europa.eu/en/publications/literature_reviews/ calculating-the-cost-of-work-related-stress-and-psychosocial-risks (07. 04. 2015)

- $\quad$ EU OSHA (2014b). Report- Psychosocial risk in Europe prevalence and strategies from prevention, https://osha.europa.eu/en/publications/reports/psychosocial-risks-eu-prevalence-strategies-prevention (07 04 2015)

- EU OSHA (2013). Report- Well- being at work: creating a positive work environment, literature review, https://osha.europa.eu/en/publications/literature_ reviews/well-being-at-work-creating-a-positive-work-environment, (07 04 2015)

- Friedman Milthon (1970): “The social responsibility of business is to increase its profits", The New York Times Magazine, September 13, 122-126, http://query.nytimes.com/mem/archivefree/pdf?res=9E05E0DA153CE531A15750C1A96 F9C 946190D6CF, (07 04 2015)

- Gilani, H.N. Mahnaz, Zadeh, S. Mohamed, Sanderi, R. Hamid (2012): " The Role of Strategic Human Resource Management in Creation of Competitive Advantages (Case Study: A Commercial Organization in Malaysia)", International Journal of Business and Social Science, 3/16, 225- 235, http:// ijbssnet.com/journals/Vol_3_No_16_Special_Issue_August_2012/24.pdf., (19 03 2015)

- Ivandić Vidović Darija, Karlović Lidija, Ostojić Alen, (2011): Korporativna sigurnost, Udruga hrvatskih menadžera sigurnosti- UHMS, Zagreb

- Jain Aditya, Leka Stavroula, Zwetsloot Gerard (2011): "Corporate Social Responsibility and Psychosocial Risk Management in Europe", Journal of Business Ethics, 101, 619- 633

- Kotler Philip, Lee Nancy (2009): Društveno odgovorno poslovanje, M.E.P. Counsult d.o.o., Zagreb

- Laurinavičius Alfonsas, Romeris Mykolas (2013): “Impact of responsible organisations to ensure socio- economic justice, Industry", Science and policy makers for Sustainable Future, proceedings of the 14th management International Conference Koper, Slovenia, 21-23 November 2013, http://www. fm-kp.si/zalozba/ISBN/978-961-266-148-9/papers/MIC1099.pdf (08. 04. 2015)

- Lapina Inga, Maurane Gunta, Starineca Olga (2014): "Human resource management models:aspects of knowledge management and corporate social responsibility", Social and Behavioural Sciences, 110, 577- 586 
- Omazić A. Mislav (2007): Društvena odgovornost i strategije hrvatskih poduzeća, PhD Thesis, University of Zagreb, Faculty of Economic and Business.

- Oraman Yasemin, Unakitan Gökhan, Selen Ufuk (2011): “Measuring Employee Expectations in a Strategic Human Resource management Research: Job Satisfaction", Social and Behavioural Sciences, 24, 413 - 420

- Polášek David (2010): Corporate Social Responsibility in Small and Medium Sized Companies in the Czech Republic, PhD Thesis, Czech management Institute Praha, Faculty of Management, Escuela Superior de Marketing y Administración Barcelona, www.csr-online.cz/wp-content/uploads/2012/.../DP_ David_Polasek.doc., (31 03 2015)

- Tamm Katrin, Eamets Raul, Motsmees Pille (2010): “Relationship Between Corporate Social Responsibility and Job Satisfaction: The case of Baltic Countries", http://www.mtk.ut.ee/sites/default/files/mtk/RePEc/mtk/febpdf/febawb76. pdf., (08 04 2015)

- Wisser Wayne (2007): “Revisiting Carroll's CSR Pyramid: An African Perspective”, In A. Crane\&D.Matten(eds.), CorporateSocialResponsibility: Three Volume Set, London: Sage, http://www.waynevisser.com/wpcontent/uploads/2012/04/ chapter_wvisser_africa_csr_pyrami d.pdf.195-212., (29 03 2015)

- Zakaria, Maziana, Abdulatiff K. Nik, Ali Norli (2014): “The role of wellbeing on performance in service sector", Social and Behavioural Science, $164,358-365$ 


\author{
Karmen Dežmar Krainz, doktorand \\ Hrvatski institut za zaštitu zdravlja i sigurnost na radu, \\ Zagreb, Hrvatska
}

\title{
UNAPREĐIVANJE BLAGOSTANJA ZAPOSLENIH U KONTEKSTU DRUŠTVENE ODGOVORNOSTI
}

\section{S a ž e t a k}

Tokom poslednjih 25 godina, tehnološki razvoj je uticao na ubrzanje procesa globalizacije što je izazvalo dramatične promene unutar i između organizacija. Poslovanje varira, kompleksno je, globalno i menja se brže nego ikada ranije. Tokom vremena, očekivanja društva su se izmenila, promene su uticale na potrošače, poslovne partnere kao i na zaposlene. Da bi opstale na globalnom tržištu, kompanije uključuju korporativnu društvenu odgovornost u svoje poslovanje sa ciljem osnaživanja njihove konkurentske pozicije. U ekonomiji znanja, u kojoj je znanje značajan resurs i tražnja za obrazovanim radnicima raste, zaposleni postaju najznačajniji i, u stvari, jedini preostali realni izazov konkurentske sposobnosti. Blagostanje na radnom mestu uključuje mentalne, psihološke i emocionalne aspekte života zaposlenih. Svest menadžmenta o blagostanju zaposlenih, koja uzima u obzir zadovoljstvo zaposlenih, njihovo zdravlje i profesionalno napredovanje je efikasan pristup jačanju organizacionog poslovanja. Cilj ovog rada je da analizira i proceni kako društveno odgovorna orijentacija inkorporirana u strategijski menadžment ljudskih resursa može da doprinese postizanju blagostanja zaposlenih. Strategijski menadžment ljudskih resursa uključuje neophodnu koordinaciju između različitih aspekata zdravlja zaposlenih i njihovih radnih performansi. Ova koordinacija doprinosti ravnoteži između privatnog i profesionalnog dela života. Društveno odgovorne aktivnosti koje su koordinisane posredstvom strategijskog menadžmenta ljudskih resursa značajno doprinose blagostanju zaposlenih kao i konkurentnosti organizacije.

Ključne reči: korporativna društvena odgovornost, strategijski menadžment ljudskih resursa, blagostanje, konkurentnost 